\title{
Perceptions of SAQA's critical cross-field outcomes as key management meta-competencies
}

\author{
T Carmichael* and A. Stacey \\ Wits Business School, PO Box 98, Wits 2050, \\ Republic of South Africa \\ Carmichael.T@wbs.ac.za
}

Received March 2006

\begin{abstract}
The critical cross-field outcomes (CCFOs) formulated by the South African Qualifications Authority (SAQA) are generic competencies designed to underpin all national qualifications registered on the National Qualifications Framework (NQF). They are intended to provide the basis for lifelong learning, personal growth, honest business acumen, critical, creative thinking and aesthetic appreciation. However, little work on these important learning outcomes has been published, despite their high face validity, and this exploratory study amongst MBA graduates is intended to stimulate interest and further research into this important area.
\end{abstract}

Although the findings cannot necessarily be generalised due to the specific sampling methodology among 53 MBA graduates from Wits Business School (graduating between 1998 and 2002), it was found that the CCFOs were collectively important to their careers, although individually, some were considered more important than others. The sample also perceived that the CCFOs were developed through the course of their studies, with use of information being developed the most, and use of technology the least.

These findings are encouraging as they imply that most of the CCFOs are intuitively important to both faculty and management students and mechanisms for systematically embedding the CCFOs into curricula may be sought and implemented to the benefit of MBA students and the business community.

*To whom all correspondence should be addressed.

\section{Introduction}

This study offers further analysis of the findings reported by Carmichael and Sutherland (2005), and focuses on MBA graduates' perceived importance of SAQA's (RSA, 1995 \& 1998; SAQA, 2001a \& 2001b) critical cross-field outcomes (CCFOs), as well as the perceived development of these generic meta-competencies during MBA study.

The study was exploratory in nature, since there is little published work on the CCFOs, specifically in the arena of management education. It was in no way intended to validate the CCFOs as they currently stand, nor to claim generalisability, but rather to review possibilities relating to their relevance in the world of business and explore their development through MBA programmes, and, further, to stimulate interest, application and further research among educators and business executives alike.

Documentation relating to the origins and development of the CCFOs appears to be mainly in the form of archival and discussion documents, most of which are not in the public domain. However, the information available suggests that they were originally drawn up on the basis of a comparison with similar generic outcomes from comparative research carried out in Australia, Brazil, Germany, Malaysia, Singapore, Tanzania, the United Kingdom (NTB, 1994; RSA, 1996; Isaacs, 1995) and later also in the United States, New Zealand and Scotland (HSRC, 1995). The intention of these generic competencies was to underpin and enable the development of the specific outcomes of learning units (Hanrahan, 1996; Hager, 1996; Bird \& Gamble, 1996). If this enabling function is valid, then it follows that lack of attention to the CCFOs could hinder the transformation of education in South Africa.

On the basis that the theoretical foundation for the CCFOs is scanty, certain assumptions have been made in this study, which the reader should take into account when evaluating the findings. Firstly, the view has been taken, that since the CCFOs are legislated (RSA, 1995 \& 1998; SAQA, 2001a \& $2001 \mathrm{~b}$ ), and therefore assumed to be of value, that they should be evaluated as they currently stand, in order to obtain an initial exploratory view of their status quo. No attempt was made to validate their relevance, completeness or appropriateness in relation to other possible constructs. This will be the topic of further study.

It has also been assumed that MBA graduates are practicing managers and would be in a position to link their learning 
through the MBA programme to its value in the workplace. Thus, the potential value of each CCFO to managers as elaborated in the discussion, is a speculative one based on a (non-exhaustive) review of pertinent literature. A further discussion relating to how they may be developed through the research process required as an integral part of MBA curricula has been included. The transferability of management skills is fundamental to workplace effectiveness (Cryer, 1998), and should take place consciously rather than sub-consciously.

\section{Problem investigation}

The identification of key skills, knowledge, attributes or competencies is subject to semantic interpretation; lists of criteria and definitions abound in the literature, and may be found in many organisations in various forms (Schoeman, 1997). For example, Ulrich, Smallwood and Zenger (1999) identified the following attributes as being key to organisational success: accountability, initiative, boundaryless thinking, integrity, commitment, conceptual thinking, communication, knowledge expertise, customer focus, quality focus, empowerment, shared ownership, global worldview, speed, influence and team-building. Mintzberg (2004:260) refers to this type of competency list as ' . . [a] mix of skills, values, traits, and even wishes, in strange ways'.

The work of Spencer and Spencer (1993) is useful in that they created clusters of generic, differentiating competencies - those that lead to superior job performance - along with behavioural indicators that can be used as measures. Superior performance (achieved by approximately one person in ten) is defined statistically as being one standard deviation above average performance (Spencer \& Spencer, 1993), and the associated salary is exponentially higher. They relate the following example:

A recent survey of 44 Southeast firms found that superior salespeople (earning an average of $\$ 41,777$ ), sold on average $\$ 6,7$ million and average performers sold on average $\$ 3$ million. The superior group sold 123 percent more than the average salespeople, a difference worth not 120 percent, but 8,857 percent (or 89 times) the average employee salary.

(Sloan \& Spencer, 1991, cited in Spencer \& Spencer, 1993: 14)

The value of superior performance to firms as well as to individuals is obvious.

\section{Competencies for managers and leaders}

Some of the assumptions inherent in the Spencer and Spencer (1993) definition of competency have been the cause of the debate around the term in more recent times. For example, they specify that a competency is part of a person's personality, rather something that a person can do (Isaacs, 2000; SAQA, 2001b \& 2003), although all agree that performance should be in accordance with agreed performance criteria. Spencer and Spencer (1993:9) also maintain that 'a competency causes or predicts behaviour and performance'. This is contradicted by Mager and Pipe (1997), who clearly differentiate competence as 'can do', from performance or 'will do' on the basis that simply because an individual is able to perform a task, it does not follow that they will.

This latter view is supported in the Situational Leadership model (Hersey, Blanchard \& Johnson, 1996), in their categories of followers, viz. a) unwilling and unable, b) willing and unable, c) unwilling and able and, lastly, d) willing and able. Here, the first two categories of individuals are task-specific 'unable' and do not have the ability to perform a specific, identified task. In the second two categories, the individual does have the ability to perform the task, so does not need further education or training. However, the unable, willing individual can, but won't perform the task. This concept is elaborated on by both Mager and Pipe (1997) and by Hersey, et al. (1996) in pointing out that poor performance is not always linked to lack of competence, a common error displayed by managers, who have been known to steer their inadequately performing staff towards the training department.

The definition proposed by Meyer (1996) and later elaborated on (Meyer \& Semark, 1998) is somewhat different to that of Spencer and Spencer (1993). They indicate that competence is the demonstration of integrated knowledge, skills, personal attributes and values.

When planning the study, Carmichael and Sutherland (2005) selected the CCFOs as the basis of management competence because they could be related to those identified by a number of early writers in the field of management, and have been further corroborated by more recent authors:

Meyer (1996) identified clusters of generic competencies that he called meta-competencies. These fall broadly into the areas of communication, gathering and interpretation of data from a variety of sources, problem solving, systems thinking, ability to apply the use of technology in the workplace, working in groups, teams or communities, using mathematical concepts and managing oneself and one's own learning and development. These metacompetencies are 'essential skills that underpin success in education, employment, lifelong learning and personal development' (United Kingdom, 2000a:2). . . .

(Carmichael \& Sutherland, 2005: 58)

And,

... The reviewed literature strongly suggests that SAQA's critical outcomes are valid competencies for leaders and managers (New Zealand, 2000; United Kingdom, 2000a, 2000b \& 2000c; AMA, 2001; Australia, 2003; Scotland, 2003), and have been described by leaders such as Guiliani (2002). In addition, Spencer and Spencer (1993) write that technical competence alone is only of value in predicting performance 
in technical tasks, but is a poor predictor of general performance in a business environment, which requires the development of human characteristics. These characteristics encompass most of the CCFOs and align well with those of Mintzberg's (2004) controversial attack on the current process and content of MBA degrees.

(Carmichael \& Sutherland, 2005:64)

A comparison of models describing the core competencies required by successful managers may be seen in Table 1 .

In South Africa, competencies are in the form of unit standards or national standards; these terms being used interchangeably:

One might take this further and say that national standards are the agreed repositories of knowledge about 'quality practice' or competence, as well as about legitimate criteria for assessing such competence. Competence, in turn, might be defined as the application of knowledge, skills and values in a specific context to a defined standard of performance.

(Isaacs, 2000:16)

The competency units to be found in the various qualifications frameworks cited above may be related to Bloom's domains of educational objectives (Bloom, 1956a $\&$ 1956b). All the country-specific qualification framework models include: the skills required to achieve a defined outcome (Bloom's psychomotor domain), certain knowledge underpinning the skill (Bloom's cognitive domain), and a statement of context. However, only the New Zealand (2000) and South African (RSA, 1995 \& 1998; SAQA, 2000; Isaacs, 2000) models include references to attitudes, attributes or values (Bloom's affective domain) (Bloom, 1956b). The affective components are difficult to measure, but can be translated into behavioural outcomes, and are key components of the competence of leaders and managers. Thus they need to be developed to build expertise.

The critical cross-field outcomes as listed in Table 1 describe the generic qualities for development in management students, regardless of their specific area or level of learning; they simply become more complex as the level of the qualification is raised (SAQA, 2001a). They are deemed by SAQA (Isaacs, 2000) to be the basis of the capacity for life-long learning as well as providing one of the underlying mechanisms for the achievement of coherence within the NQF. They are intended to direct the thinking of curriculum designers, learning facilitators and the learners themselves.

The outcomes are considered so fundamental that it is mandatory for the writers of unit standards to incorporate at least some of them into all of the standards that they write, and for all of them to be incorporated into qualifications at the appropriate NQF level (Isaacs, 2000). The inclusion of the CCFOs must be explained within the text of the unit standard or qualification, and each linked to the specific outcome or assessment criterion through which it will manifest. The critical outcomes should be integrated into the core learning and assessment of all qualifications and unit standards.

\section{Criticisms of current management education}

In 1993, Randall expressed concern that developments in education in South Africa would not be sufficiently transformational. He felt that learning should:

\begin{abstract}
. . .increase people's capacity to discover, define, pursue and achieve common objectives, and in the process, to develop more confident relationships with one another and the outside world.
\end{abstract}

(Randall, 1993:15)

Two years later, Boyatzis, Cowen and Kolb (1995) criticised the types of competence that were emerging as a result of management education. They cite a number of sources that have identified, in a general sense, MBA graduates' deficiencies. They: a) are not practical enough, b) lack interpersonal skills, particularly in communication, c) are insufficiently global in their thinking, d) have unreasonably high expectations about promotion after graduating, e) are insufficiently acquainted with the use of information resources and $\mathrm{f}$ ) do not work well in groups.

More recently Mintzberg (2004:5), sent business schools around the world reeling from the stern and pointed admonition that, 'It is time to recognize conventional MBA programs for what they are - or else close them down. They are specialised in training in the functions of business, not general educating in the practice of managing.' He (Mintzberg, 2004) goes on to describe in detail what he calls the corruption of the educational process, of managerial practice, of established organisations and finally, of social institutions. He demands a new type of MBA, one that focuses on management development, including the critical competencies that he identifies in Table 1, rather than management education, which would tend to build knowledge only and not necessarily skills that can be applied in a variety of contexts. The concerns voiced by these authors refer to characteristics that should be developed through the emergence of the critical cross-field outcomes as educational processes are implemented, at all levels of the NQF.

\section{Objectives}

The objectives of the study were to conduct an initial exploratory investigation into the perceptions of MBA graduates from Wits Business School regarding a) the relative importance of SAQA's CCFOs as key generic management meta-competencies, and b) the extent to which they perceived the CCFOs to be developed during their MBA studies. 
Table 1: An illustrative matrix of assessable generic meta-competencies

\begin{tabular}{|c|c|c|c|c|c|}
\hline $\begin{array}{c}\text { Isaacs (2000); SAQA } \\
\text { (2001) } \\
\text { Critical cross-field } \\
\text { outcomes }\end{array}$ & $\begin{array}{l}\text { Meyer (1996) } \\
\text { Meta- } \\
\text { competencies }\end{array}$ & $\begin{array}{l}\text { United Kingdom } \\
\text { (2000b) } \\
\text { Key Skills }\end{array}$ & $\begin{array}{l}\text { AMA (2001) } \\
\text { Competency } \\
\text { Categories }\end{array}$ & $\begin{array}{c}\text { Spencer \& Spencer } \\
\text { (1993) } \\
\text { Management } \\
\text { competencies }\end{array}$ & $\begin{array}{c}\text { Mintzberg (2004) } \\
\text { List of Managerial } \\
\text { competencies (p 260) }\end{array}$ \\
\hline $\begin{array}{l}\text { Solve problems: } \\
\text { Identifying and solving } \\
\text { problems in which } \\
\text { responses display that } \\
\text { responsible decisions } \\
\text { using critical and } \\
\text { creative thinking have } \\
\text { been made }\end{array}$ & $\begin{array}{l}\text { - Solve complex, } \\
\text { multi- } \\
\text { dimensional } \\
\text { problems }\end{array}$ & $\begin{array}{l}\text { - Problem } \\
\text { Solving }\end{array}$ & & $\begin{array}{l}\text { - } \begin{array}{l}\text { Conceptual } \\
\text { thinking }\end{array} \\
\text { - Analytical } \\
\text { thinking } \\
\text { - Impact and } \\
\text { influence }\end{array}$ & $\begin{array}{l}\text { - Informational, personal and } \\
\text { additional competencies, eg } \\
\text { designing, mobilising, } \\
\text { administering, processing } \\
\text { information, and facilitating }\end{array}$ \\
\hline $\begin{array}{l}\text { Use of Information: } \\
\text { Collecting, analysing, } \\
\text { organising and critically } \\
\text { evaluating information }\end{array}$ & $\begin{array}{l}\text { - Locate and } \\
\text { interpret } \\
\text { relevant } \\
\text { information } \\
\text { from written, } \\
\text { electronic and } \\
\text { human sources }\end{array}$ & & $\begin{array}{l}\text { - Conceptual } \\
\text { Skills }\end{array}$ & $\begin{array}{l}\text { - Information } \\
\text { seeking } \\
\text { - Analytical } \\
\text { thinking }\end{array}$ & $\begin{array}{l}\text { Informational competencies, } \\
\text { including data processing, } \\
\text { modelling, evaluating }\end{array}$ \\
\hline $\begin{array}{l}\text { - Systems thinking } \\
\text { Demonstrating an } \\
\text { understanding of the } \\
\text { world as a set of related } \\
\text { systems by recognising } \\
\text { that problem-solving } \\
\text { contexts do not exist in } \\
\text { isolation }\end{array}$ & $\begin{array}{l}\text { - Use processes } \\
\text { of analysis, } \\
\text { synthesis and } \\
\text { systemic } \\
\text { thinking; } \\
\text { - Innovatively } \\
\text { apply } \\
\text { knowledge and } \\
\text { skills in } \\
\text { changing } \\
\text { situations and } \\
\text { to manage } \\
\text { change } \\
\text { effectively; }\end{array}$ & & & $\begin{array}{l}\text { - } \begin{array}{l}\text { Conceptual } \\
\text { thinking }\end{array} \\
\text { - Analytical } \\
\text { thinking } \\
\text { - Organisational } \\
\text { awareness }\end{array}$ & $\begin{array}{l}\text { Personal, Interpersonal, } \\
\text { informational and additional } \\
\text { competencies }\end{array}$ \\
\hline $\begin{array}{l}\text { - Communicate } \\
\text { effectively } \\
\text { Communicating } \\
\text { effectively using visual, } \\
\text { mathematical and/or } \\
\text { language skills in the } \\
\text { modes of oral and/or } \\
\text { written persuasion }\end{array}$ & $\begin{array}{l}\text { Communicate } \\
\text { effectively with } \\
\text { diverse groups } \\
\text { of people and } \\
\text { individuals on } \\
\text { complex issues; }\end{array}$ & $\begin{array}{l}\text { - Communication, } \\
\text { Numeracy } \\
\text { (called } \\
\text { Application of } \\
\text { Number), }\end{array}$ & $\begin{array}{l}\text { - Communication } \\
\text { skills }\end{array}$ & $\begin{array}{l}\text { - } \\
\text { - Impact and } \\
\text { influence }\end{array}$ & $\begin{array}{l}\text { - Interpersonal and } \\
\text { informational competencies } \\
\text { - Information gathering and } \\
\text { processing, presenting, } \\
\text { writing, speaking, } \\
\text { organising, listening, verbal } \\
\text { and non-verbal skills, etc }\end{array}$ \\
\hline $\begin{array}{l}\text { Use technology: Using } \\
\text { science and technology } \\
\text { effectively and critically, } \\
\text { showing responsibility } \\
\text { towards the environment } \\
\text { and health of others }\end{array}$ & $\begin{array}{l}\text { - Apply scientific } \\
\text { and } \\
\text { mathematical } \\
\text { concepts and } \\
\text { use relevant } \\
\text { technology } \\
\text { effectively; }\end{array}$ & $\begin{array}{l}\text { - Information } \\
\text { Technology }\end{array}$ & $\begin{array}{l}\text { - Conceptual } \\
\text { skills }\end{array}$ & $\begin{array}{l}\text { - Analytical } \\
\text { thinking }\end{array}$ & $\begin{array}{l}\text { Additional competencies, eg } \\
\text { scheduling, systematising, } \\
\text { project managing }\end{array}$ \\
\hline
\end{tabular}




\begin{tabular}{|c|c|c|c|c|c|}
\hline $\begin{array}{c}\text { Isaacs (2000); SAQA } \\
\text { (2001) } \\
\text { Critical cross-field } \\
\text { outcomes }\end{array}$ & $\begin{array}{l}\text { Meyer (1996) } \\
\text { Meta- } \\
\text { competencies }\end{array}$ & $\begin{array}{l}\text { United Kingdom } \\
\text { (2000b) } \\
\text { Key Skills }\end{array}$ & $\begin{array}{l}\text { AMA (2001) } \\
\text { Competency } \\
\text { Categories }\end{array}$ & $\begin{array}{c}\text { Spencer \& Spencer } \\
\text { (1993) } \\
\text { Management } \\
\text { competencies }\end{array}$ & $\begin{array}{c}\text { Mintzberg (2004) } \\
\text { List of Managerial } \\
\text { competencies (p 260) }\end{array}$ \\
\hline $\begin{array}{l}\text { Work with others: } \\
\text { Working effectively with } \\
\text { others as a member of a } \\
\text { team, group, } \\
\text { organisation, community }\end{array}$ & $\begin{array}{l}\text { - Operate } \\
\text { effectively in } \\
\text { multi- } \\
\text { disciplinary } \\
\text { teams; }\end{array}$ & $\begin{array}{l}\text { - Working with } \\
\text { Others }\end{array}$ & $\begin{array}{ll}\text { - } & \text { Interpersonal } \\
\text { skills } \\
\text { - } & \text { Team } \\
& \text { leadership }\end{array}$ & $\begin{array}{ll}\text { - } & \text { Interpersonal } \\
\text { understanding } \\
\text { - } & \text { Customer } \\
\text { service } \\
\text { - } & \text { Networking } \\
\text { - } & \text { Relationships } \\
\text { - } & \text { Teamwork } \\
\text { - } & \text { Impact and } \\
\text { influence } \\
\text { - } & \begin{array}{l}\text { Developing } \\
\text { others }\end{array}\end{array}$ & $\begin{array}{l}\text { - Interpersonal competencies } \\
\text { including leading } \\
\text { individuals, teams, business } \\
\text { units, organisations } \\
\text { - Collaboration, networking, } \\
\text { negotiation, promoting, } \\
\text { organising, listening, } \\
\text { resolving conflict, etc }\end{array}$ \\
\hline $\begin{array}{l}\text { - Self-management } \\
\text { Organizing and } \\
\text { managing oneself and } \\
\text { one's activities } \\
\text { responsibly and } \\
\text { effectively }\end{array}$ & $\begin{array}{l}\text { - Use time } \\
\text { effectively and } \\
\text { to manage a } \\
\text { variety of tasks; } \\
\text { - Manage one's } \\
\text { own, often } \\
\text { multiple career } \\
\text { and balance } \\
\text { occupational, } \\
\text { family, } \\
\text { community and } \\
\text { other demands } \\
\text { effectively. }\end{array}$ & $\begin{array}{l}\text { - Improving Own } \\
\text { Learning and } \\
\text { Performance. }\end{array}$ & $\begin{array}{ll}\text { - } & \text { Effectiveness } \\
\text { skills } \\
\text { - } & \text { Order, quality } \\
\text { and accuracy }\end{array}$ & $\begin{array}{ll}\text { - } & \begin{array}{l}\text { Achievement } \\
\text { orientation }\end{array} \\
\text { - } & \text { Initiative } \\
\text { - } & \text { Self-control } \\
\text { - } & \text { Self-confidence } \\
\text { - } & \text { Flexibility } \\
\text { - } & \text { Organisational } \\
\text { commitment } \\
\text { - } & \text { Job related } \\
\text { expertise }\end{array}$ & $\begin{array}{l}\text { Managing oneself, both } \\
\text { internally (reflection, } \\
\text { strategic thinking) and } \\
\text { externally (time, stress, } \\
\text { career, information) }\end{array}$ \\
\hline
\end{tabular}

Sources: As per column heading

\section{Research methodology}

The study was quantitative and exploratory, seeking the opinions and perceptions of graduated MBA students (Miles \& Huberman, 1994; Carter, 1997; Leedy \& Ormrod, 2001; Robson, 2002). The survey questionnaire consisted of a list of the seven assessable CCFOs, and respondents were required to consider the CCFO's from two perspectives. Firstly, they were a) to rate the perceived importance of each CCFO using a 100 point constant sum scale, and b) then to indicate the extent to which they perceived each CCFO to be developed during their course of study using a three point verbal ordinal scale from 'Did not improve' to 'Greatly improved'. The list of CCFOs included a category labelled 'other' to allow respondents to propose any additional key meta-competencies if they wished.

\section{Population and sample}

The population was defined to include all MBA students who graduated between the years 1998 and 2002 from Wits Business School. The sample was drawn on a nonprobability convenience basis, taking care to assure that the race and gender profile (quota sampling, as per Leedy \& Ormrod, 2001) was representative of recent (over the past 5 years) MBA classes. The lack of sources with stratified demographic information made stratified random sampling
(Robson, 2002) problematic, although this approach would have yielded more generalisable data. However, although statistical inference and generalisation are not claimed here, qualitative data can be transferable (Bendixen, 2002), and it is anticipated that the findings here will be useful to MBA facilitators, managers and MBA students.

The 53 useable responses were sufficient to meet the requirements of the central limit theorem. Using the Chisquare test, the demographic profile (gender and race) of the respondents was shown not to be significantly different from that of recent MBA classes $\left(\chi^{2}=2,81, d\right.$ f. $\left.=5, p=0,7297\right)$. Table 2 illustrates.

\section{Limitations and delimitations of the study}

Because respondents were selected from one business school only, and were selected on a convenience basis, the sample may have been biased (Leedy \& Ormrod, 2001; Robson, 2002). Thus, readers should not necessarily assume that the findings reported here can be generalised to their own institutions, although it may be possible to transfer them usefully to similar contexts (Bendixen, 2002). Further research may provide additional support for the findings reported here. 
Table 2: The demographic variables of the respondents and $\mathrm{Chi}^{2}$ calculation

\begin{tabular}{|c|c|c|c|c|}
\hline \multicolumn{5}{|c|}{ Expected Proportions } \\
\hline & Asian / Coloured & Black & White & \\
\hline Male & $15,29 \%$ & $20,50 \%$ & $37,05 \%$ & \\
\hline Female & $5,22 \%$ & $8,45 \%$ & $13,49 \%$ & \\
\hline \multicolumn{5}{|c|}{ Observed Frequencies } \\
\hline & Asian / Coloured & Black & White & Total \\
\hline Male & 7 & 7 & 23 & 37 \\
\hline Female & 4 & 4 & 8 & 16 \\
\hline Total & 11 & 11 & 31 & 53 \\
\hline \multicolumn{5}{|c|}{ Expected Frequencies } \\
\hline & Asian / Coloured & Black & White & \\
\hline Male & 8,10 & 10,87 & 19,64 & \\
\hline Female & 2,76 & 4,48 & 7,15 & \\
\hline \multicolumn{5}{|c|}{ Chi $^{2}$ Contributions } \\
\hline & Asian / Coloured & Black & White & \\
\hline Male & 0,15 & 1,38 & 0,58 & \\
\hline \multirow[t]{4}{*}{ Female } & 0,55 & 0,05 & 0,10 & \\
\hline & & & $\mathrm{Chi}^{2}=$ & 2,81 \\
\hline & & & $\mathrm{d} \mathrm{f.}=$ & 5 \\
\hline & & & $\mathrm{p}$ value $=$ & 0,7297 \\
\hline
\end{tabular}

The high face validity of the CCFOs, suggested by the fact that all were weighted by the respondents and a negligible number of others were suggested, coupled with the dearth of scientific research into their application, demands further research if they are to be taken seriously by educators. This applies both in formal educational institutions as well as within corporate training and education units.

\section{Results of the study}

\section{The perceived relative importance of the CCFOs}

Table 3 gives the sample means, standard deviations, confidence intervals and significance of the importance weightings attributed to each CCFO by the respondents. In this table, the mean value associated with each CCFO is expressed as a percentage of the sum total importance of all CCFOs.

Table 3 shows a marked difference in the perceived importance of the critical outcomes. The low relative importance attributed to the use of technology is noteworthy, given the highly computerised business environment of today's rapidly changing global economies (Nordstrom \& Ridderstrale, 2002).
A mean weight of only $2.3 \%$ was allocated to 'Other', suggesting that all seven assessable critical cross-field outcomes were perceived to be relevant (albeit variably) to MBA students, and no meaningful others were suggested. However, this interpretation should be viewed cautiously, since it is known that greater response rates are achieved when using prompted variables than unprompted variables.

\section{The perceived development of the CCFOs}

The verbal ordinal response data were analysed using a lognormal distribution fitting algorithm approach suggested by Stacey (2005). Using this approach, distributions (in this instance, lognormal distributions) are fitted to the observed survey data using the $\chi^{2}$ statistic to optimise the fit. Estimates of the underlying population means and standard deviations of each survey item are thus obtained (being the means and standard deviations of the best fitting distributions). These estimates of mean and standard deviation have been shown to be more reliable and valid than those obtained using conventional analysis, which assumes the verbal ordinal level data to be interval scaled (Stacey, 2005). 
Table 3: Table of sample means and standard deviations of CCFO weightings

\begin{tabular}{|c|c|c|c|c|c|}
\hline \multirow[b]{2}{*}{$\mathrm{CCFO}$} & \multirow[b]{2}{*}{ Mean } & \multirow{2}{*}{$\begin{array}{l}\text { Standard } \\
\text { Deviation }\end{array}$} & \multicolumn{2}{|c|}{$90 \%$ Confidence Interval } & \multirow{2}{*}{$\begin{array}{l}\text { Significance } \\
\quad(\alpha=10 \%)\end{array}$} \\
\hline & & & Lower Limit & Upper Limit & \\
\hline Solve problems & $18,1 \%$ & $6,8 \%$ & $19,7 \%$ & $16,6 \%$ & ++ \\
\hline Work with others & $16,2 \%$ & $6,6 \%$ & $17,7 \%$ & $14,7 \%$ & ++ \\
\hline Self-management & $11,5 \%$ & $6,7 \%$ & $13,1 \%$ & $10,0 \%$ & -- \\
\hline Use of Information & $16,6 \%$ & $7,0 \%$ & $18,2 \%$ & $15,0 \%$ & ++ \\
\hline Communicate effectively & $14,2 \%$ & $7,3 \%$ & $15,8 \%$ & $12,5 \%$ & \\
\hline Use of technology & $7,4 \%$ & $5,7 \%$ & $8,7 \%$ & $6,1 \%$ & -- \\
\hline Systems thinking & $13,7 \%$ & $6,9 \%$ & $15,3 \%$ & $12,1 \%$ & \\
\hline Other & $2,3 \%$ & $6,0 \%$ & & & \\
\hline
\end{tabular}

Table 4 gives the sample means, standard deviations, confidence intervals and significance of the extent to which respondents perceived each $\mathrm{CCFO}$ to have been developed during their MBA studies. In this table, the mean value associated with each CCFO is expressed as a percentage of the mean development, averaged across all CCFOs. Therefore, a mean value significantly greater than $100 \%$ is associated with a CCFO where the development is significantly more than the average; a mean value significantly less than $100 \%$ is associated with a CCFO where the development is significantly less than the average,

Respondents perceived that all CCFOs were developed during their MBA studies, although to different extents. Most strongly developed were the ability to solve problems, use of information and systems thinking; the development of these CCFO's was significantly above the overall average (significance level, $\alpha=10 \%)^{1}$. Use of technology and selfmanagement were developed the least, and were developed significantly less than the overall average (significance level, $\alpha=10 \%$ ).

\section{Composite analysis of the importance / development data}

The relationship between the importance weightings and the extent to which each CCFO has been developed during the MBA programme are illustrated in Figure 1. This chart differentiates the critical cross-field outcomes in terms of their importance to the student and the extent to which they were perceived to be developed.

The situation of a particular critical cross-field outcome on the vertical axis (weight) indicates its importance to the sample relative to the other critical cross-field outcomes. It can be seen in Figure 1, that because 'solve problems' is the highest on the vertical axis, it was perceived to have the greatest importance, whereas 'use technology' had the least importance. Any CCFO situated on the horizontal axis to the

\footnotetext{
${ }^{1}$ The significance level of $10 \%$ was selected on the basis of the
} exploratory nature of the research. right of $100 \%$ was perceived to be developed to a greater extent during the course of the MBA than average, and those to the left of $100 \%$ were developed less than average. Thus, 'use of information' was developed to the greatest extent, and 'use technology' was developed the least.

An example of the usefulness of the Figure 1 plot to business schools could be represented by the large distance between 'use technology', which was perceived as relatively unimportant and was the least well developed during the MBA, and 'use of information', which was relatively important and was the best developed of these outcomes during the MBA. It may be of value to students to demonstrate how technology (eg computer technology) could be used to evaluate information critically and creatively with the use of appropriate software, which would enable them to make better business decisions.

The research has demonstrated that there is a more or less linear relationship between the MBA graduates' perceptions of the importance and their perceptions of the extent to which each CCFO was developed in MBA programmes. Thus, those perceived to be important were also perceived to be well developed during the programme. This raises the unanswered chicken-and-egg question of a) whether students and / or faculty perceive certain of them to be important, and therefore apply themselves more to their development, or b) whether certain of them are simply not addressed during the study programme and are therefore perceived to be less important, as demonstrated by the CCFO 'use technology'. It is also possible that selective learning took place and students only learned what they, the students, considered important.

Randall's (1993) concerns about education in South Africa being insufficiently transformational could be allayed if these core competencies were to be developed at all NQF levels. His suggestion was that educational programmes should enable people to build awareness of and interact cooperatively with the world and others around them, to improve their productivity and develop a pragmatic, problem-solving outlook. 
Table 4 : Table of Sample Means and Standard Deviations of Relative Development of CCFOs

\begin{tabular}{|c|c|c|c|c|c|}
\hline \multirow[b]{2}{*}{$\mathrm{CCFO}$} & \multirow[b]{2}{*}{ Mean } & \multirow{2}{*}{$\begin{array}{l}\text { Standard } \\
\text { Deviation }\end{array}$} & \multicolumn{2}{|c|}{$90 \%$ Confidence Interval } & \multirow{2}{*}{$\begin{array}{c}\text { Significance } \\
(\alpha=10 \%)\end{array}$} \\
\hline & & & Lower Limit & Upper Limit & \\
\hline Solve problems & $112,6 \%$ & $44,6 \%$ & $122,9 \%$ & $102,3 \%$ & ++ \\
\hline Work with others & $108,0 \%$ & $56,4 \%$ & $121,0 \%$ & $95,1 \%$ & \\
\hline Self-management & $80,9 \%$ & $42,9 \%$ & $91,1 \%$ & $70,6 \%$ & -- \\
\hline Use of Information & $122,7 \%$ & $53,4 \%$ & $135,0 \%$ & $110,4 \%$ & ++ \\
\hline Communicate effectively & $91,2 \%$ & $38,3 \%$ & $100,1 \%$ & $82,3 \%$ & \\
\hline Use of technology & $68,8 \%$ & $43,3 \%$ & $79,1 \%$ & $58,5 \%$ & -- \\
\hline Systems thinking & $114,3 \%$ & $58,9 \%$ & $127,9 \%$ & $100,6 \%$ & ++ \\
\hline
\end{tabular}

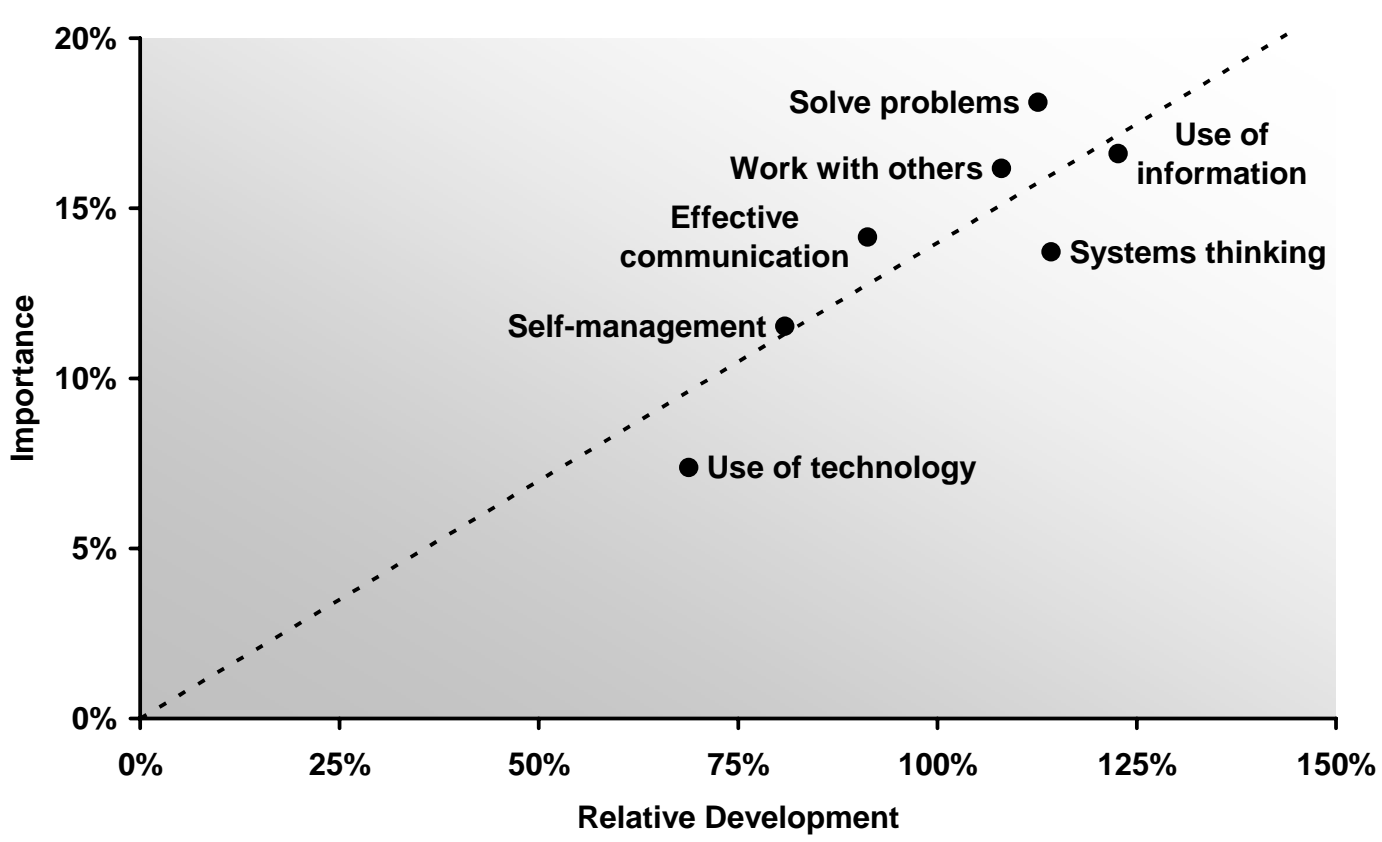

Figure 1: A plot of the assessable critical cross-field outcomes; importance versus development during an MBA

\section{Discussion of the findings}

The importance and role of the CCFOs to managers and leaders is clearly still little appreciated as yet, and there may be a number of possible reasons for this. One may be that unit standards and qualifications required under the SAQA legislation (RSA, 1995) are still being developed. Another may be that there is so little published work in this area, and, like the low perceived relative importance of some of the CCFOs found in this study, may lead academics and educators alike to perceive that they are therefore not important. Furthermore, it is suspected that the attention of the Standards Generating Bodies (SGBs) has focused on the functional, work related outcomes within unit standards and qualifications, at the expense of the CCFOs and their foundational, underpinning role in educational efforts and management competence. The commonalities between these fundamental outcomes and others around the world as revealed in Table 1, emphasises their importance and the need for a great deal more academic focus on their development.

As a point of illustration, Guiliani (2002), in the aftermath of September 11, describes the leadership qualities that enabled him to make a difference, and one can only imagine the problem-solving abilities, critical evaluation of information, understanding the interrelationships of issues, communication, effective use of technology and team work required in that particular scenario.

The interdependence of the critical cross-field outcomes and the underlying importance of technology may be illustrated by examining in more detail how they may interlink in a business setting.

i. Identifying and solving problems in which responses display that responsible decisions using critical and creative thinking have been made 
Problem solving proficiency (Bagayoko, Kelley \& Hasan, 2000; Kirkwood, 2000), leading to the making of sound managerial decisions, can result in great financial success, or conversely, to 'poor product and service mix, disastrous pricing decisions, misplaced expenditure and turf battles that destroy people and an organisation's ability to compete' (Kelly, 1996:4). Higher order thinking (Kirkwood, 2000) allows the individual to consider multiple interpretations, accommodate uncertainty, find order in chaos and often yields multiple possible solutions. Such thinking requires developed creativity through both convergent (teams excel here) and divergent (more an individual ability) cognitive approaches (Thompson, 2003). Rowley and Slack 1998) highlight lack of student critical thinking and reasoning ability as a barrier to learning.

Clear, critical thinking is the art of being able to logically assess claims (of truth) according to specified general principles in order to separate truth from non-truth (Dauer, 1989; Ruchlis \& Oddo, 1990). This enables one to make better decisions based on the information available. Critical thinking abilities enable managers to act fairly and democratically, to take initiative and to be aware of distortion and bias (Brookfield, 1987).

\section{ii. Working effectively with others as a member of a team, group, organisation, and community.}

By definition, teams, groups, organisations and communities consist of groups of people, who, by pooling their individual talents and resources, may create environments of synergy so that all are exponentially better off than simply the sum of their collective talents and resources would allow (Moorhead \& Griffin, 1995; Charlton, 2000; Robbins, 2001). Teams (Hunter, Bailey \& Taylor, 1998:79) 'work together to achieve a purpose ... are co-operative structures . . . a form of group intelligence'. The concept of corporate emotional intelligence (Carmichael, Wallace \& Rijamampianina, 2005) encapsulates the idea that executives who integrate their emotional intelligence (Goleman, 1995 \& 2000) capabilities can achieve strategic decision-making synergies enabling sustainable competitive advantages for their organisations.

Teams, in the form of functional, divisional, project, workgroup, or cross-functional groups are commonly found in organisations for the purpose of solving more complex problems or performing more complex tasks than an individual could alone (Hunter et al., 1998). Robbins (2001) does point out, however, that teams are not suitable for all types of work, and that they should be used only when appropriate.

Handy (1994) describes businesses as communities of people, and, as workplace environments change at an everincreasing increasing pace (Nordstrom \& Ridderstrale, 2002), different ways of belonging to one's different communities need to emerge (Hunter et al., 1998). Organisation and community leaders need to able to contribute meaningfully to the goals of those communities. Management is essentially about getting results through others, and the success of a manger depends to an extent on their ability to do this effectively (Robbins, 2001).
Since the recognition of people as one of the key factors for organisational success (Schoeman, 1997), working effectively in groups is key to management success. This encompasses all areas of group dynamics, including group development, decision making and productivity, as well as inter-group dynamics (Moorhead \& Griffin, 1995). This last factor is important, for example, in creating strategic horizontal alignment within organisations by removing functional, divisional or geographic barriers (Fitz-enz, 2000).

\section{iii. Organizing and managing oneself and one's activities responsibly and effectively.}

The concepts implicit in this outcome operate at many levels (United Kingdom, 2000b; SAQA, 2001a). Fundamentally, it implies the application of skills such as time management, goal setting (Canfield, Hansen \& Hewitt, 2000; Mintzberg, 2004), and project management, establishing personal workflow processes, personal operating principles and even dealing with e-mail and telephone calls (Robbins, 2001; Moorhead \& Griffin, 1995). At a deeper level it encompasses the concept of personal mastery (Senge, 1990; Senge, Kleiner, Roberts, Ross \& Smith, 1994), requires an enquiring mind to constantly seek better and more efficient ways of meeting one's objectives and leveraging off available resources (Canfield, et al., 2000), and also sharing those learnings with others.

Organising and managing oneself implies self-application of the fundamental management principles of planning, organising, leading and controlling, including the delivery of agreed outputs according to specified criteria (Robbins, 2001). Self-management is about integrity (Canfield et al., 2000), self-leadership, personal accountability and trustworthiness (King, 2002), all of which link to the concept of responsible citizenship, particularly in the face of Africa's 'Catastrophic Corruption' (Szeftel, 2000:287). Computer technology is an integral part of all management functions (Boyatzis, et al., 1995), not least the control function, and business leaders are directed to ensure that the responsibility for implementing internal quality assurance and conformance control mechanisms is supported by the necessary computer skills being in place (Garratt, 1996; King, 2002).

Knowledge management and information technology have also become key drivers of business strategy (King, 2002), and are core competencies in the knowledge economy (Nordstrom \& Ridderstrale, 2002). A great deal of communication, including the transfer of learning, takes place via the medium of e-mail and the Internet, especially in geographically dispersed and global organisations.

\section{iv. Collecting, analysing, organising and critically evaluating information.}

Collecting, analysing, organising and critically evaluating information is fundamental to making well-founded business decisions and solving problems (Kirkwood, 2000); managers need business expertise for dealing with realworld issues. Managing information in this way presupposes an ability to read critically and evaluatively (Davies, 1996). 
A major source of reliable information is peer-reviewed published journal articles (Bendixen, 2002), followed by other academic texts, whereas un-reviewed journal articles, magazine articles, newspaper reports and popular writings are not reliable information sources, and may be frankly misleading. Developing the ability to differentiate reliable from unreliable information would stand organisational decision makers in good stead.

Davies (1996) describes critical reading as an objective, unprejudiced evaluation of a text, taking into account an appropriate definition of the problem, sample validity, the identification of biases or confounding variables, the extent of subjective interpretation of results, the outcome measures and the generalisability of the findings. Such critical reading ability would not only enable executives to judge the quality of the information they receive, but also to critically evaluate the reports of others (Boyatzis et al., 1995). This would stand them in good stead as decision makers, as well as validating the Master's level of the MBA qualification (SAQA, 2001a), which requires such abilities. The ability to read in this way is extensively developed through the research process, which is a major part of accredited MBA degrees.

Since information literacy (Karelse, 1998) is a vehicle for self-directed learning and knowledge creation, enabling individuals to participate in the global information society, it is a particularly important critical outcome. Information analysis in a business context generally also requires an appropriate level of numerical competence (Boyatzis et al., 1995; Isaacs, 2000). This is to enable the application of computer-based resources such as databases and spreadsheet programmes to analyse, communicate and store large volumes of information (Boyatzis, et al., 1995). It is selfevident that, to be successful, business executives no longer have the option of numerical or computer literacy.

Business schools have huge resources of knowledge available in their libraries. Students would benefit academically if they were able to more effectively utilise these resources, a skill that business schools could support by integrating 'learning to learn' concepts into the programmes that they offer (Boyatzis et al., 1995). Not only would this help students cope with an ever increasing volume of material, but would also facilitate better learning outcomes and instil an attitude of life-long learning as encouraged by SAQA (2000). Students who demonstrate a high level of applied competence on their return to the workplace are likely to experience an enhanced ROI for their educational investment (Carmichael \& Sutherland, 2005).

Although information is derived from data, and thus the two are not the same, Kelly (1996) describes the importance of building confidence in management decisions by basing decisions on reliable data, encouraging decision makers to refer to the source of information. He describes the emotional manoeuvring and manipulations evident in many strategic meetings, resulting from attachment to uninformed opinion, gut feeling or anecdotal example. These effects are significantly reduced by the introduction of valid, reliable data, which may be obtained from scholarly publications
(Bendixen, 2002). Those with high levels of information literacy (Karelse, 1998) and the ability to read critically (Davies, 1996), will be in a position to differentiate and apply the more reliable sources to inform their thinking.

\section{v. Communicating effectively using visual, mathematical and / or language skills in the modes of oral and / or written persuasion.}

Business communication in many parts of the world, including much of South Africa, is carried out in English (Bruton-Simmonds, 1992), and it follows that, in our globally emerging economy, it is necessary for current and aspirant business executives to be fluent in this language. The medium of instruction at the major business schools in South Africa is English. Locally, business communication is complicated by the fact that there are 11 official languages and English is not the first language of the vast majority of the population.

Communication is not only about careful choice of words and an appropriate vocabulary (Bruton-Simmonds, 1992), but also the important non-verbal components such as tone, nuance, emphasis and body language (Pease, 1993). Misuse of these may lead to the wrong message being heard (Morris, 1982).

This critical outcome includes communication mechanisms such as speeches, presentations, facilitation, training, coaching and mentoring, as well as communication channels, for example publications, advertising, videos, tape recordings, and slide presentations, which may be either written or verbal (Pease, 1993; Pease \& Dunn, 1995; Mintzberg, 2004). Each of these has its own attendant rules, best practices and mechanisms.

The functions and processes of communication are also included in this critical outcome, as are barriers to communication and how to overcome them. Informal and formal communication channels are important in organisations, and often relate to politics and power dynamics within companies, factors usually of great concern to managers (Robbins, 2001). Gender and cultural differences may easily complicate communication, especially in today's highly diverse and politically correct society.

Written communications in organisations include instructions, policies, reports, Acts, training materials, assessments, media releases, strategy documents, proposals, and so on. They may be disseminated formally or informally, including by e-mail, which has developed its own protocol. Information and knowledge management systems store and dispense communications in specific formats and at appropriate times or on demand, as specified by a particular organisation (Moorhead \& Griffin, 1995).

Clearly, communication in all its forms is crucial for corporate success, and managers need to identify the 'who, what, why, how, when and where' of the communications under their control in order for them to be effective. 
vi. Using science and technology effectively and critically, showing responsibility towards the environment and health of others.

An early description of this CCFO (RSA, 1996) suggests that learners should be able to use processes, techniques and tools as well as technological devices (including computers) to gather information, solve problems, and create and evaluate products. Furthermore, they should use technologies wisely and evaluatively, taking into account both their effectiveness and any consequences for others as well as the environment.

However, interpretation of this critical outcome can, and should, be extended to include all forms of science and technology developed subsequently. It has been assumed to encompass aspects including, but not limited to, the use of computer technology, factory and operations management along with the environmental and health impact of such operations, including waste and emissions management, noise and other forms of pollution, management and sustainability of natural resources and other forms of socially responsible economic development.

In the business context, managers of functions such as those described above would be required to think beyond the short-term objectives of profit maximisation and embrace the fact that longer-term sustainability issues need to be factored into their operations. The consequences of their business decisions need to be carefully thought through before the implementation of plans, implying that a longterm orientation would be important. However, Hofstede's (1994) dimensions of national culture reflect that he only discovered of the fifth dimension, being long-term orientation (LTO) versus short-term orientation, in the East Asian countries, not the westernised ones.

Further research into the applicability of Hofstede's (1994) dimensions in the South African business context (Thomas \& Bendixen, 2000) revealed that South African managers have a tendency, like most western cultures, to be more short-term focused. This suggests that there could be some difficulties in applying this CCFO, although Hofstede's (1994:14) comment relating to LTO and economic growth could encourage South African managers to adopt a longerterm approach:

The highest scores on the fifth dimension are all found in East Asian countries: Hong Kong, Taiwan, Japan. As these are also the countries with the world's fastest rates of economic growth in the past twenty-five years, we can say that long-term orientation is strongly related to recent economic growth.

vii. Demonstrating an understanding of the world as a set of related systems by recognising that problem-solving contexts do not exist in isolation.

This CCFO encompasses two major themes; systems and context (NTB, 1994; RSA, 1996). In relation to this CCFO, a system is defined (RSA, 1996: Appendix D, p.6) as 'an ecological, legal, social, or economic unit of organisation made up of independent parts', and learners are expected to 'participate in democratic structures and processes ... through understanding and engaging with a range of interlocking systems' (NTB, 1994: Appendix F, p.F1). The description goes on to encourage evaluation and resolution of problems through consideration of the broad sociopolitical contexts at play.

The systems thinking conceptual framework as defined by Senge (1990) has become a key strategic tool in business since it was published 13 years ago. The concept has been applied, elaborated in many business contexts and widely published (Senge, 1990; McCaughan \& Palmer, 1994; Senge et al., 1994). This type of thinking is key to executive data gathering and decision making because it makes it more likely that all relevant information will be gathered and taken into account when defining contexts and implications in solving specific problems (Senge, 1990).

As with a research undertaking (Leedy \& Ormrod, 2001), contextual clarification of the problem before one begins to work on it is crucial to its successful resolution; systems thinking supports this logical approach (McCaughan \& Palmer, 1994).

\section{The place of MBA research in the development of CCFOs}

The inclusion of research at Master's level is not optional in terms of SAQA's level descriptors (SAQA, 2001a), and an undertaking of this nature is one of the key differentiators from a Bachelor's degree. Made explicit in the level descriptors for a Master's degree are the ability to 'generate, evaluate and synthesise information and concepts at highly abstract levels', 'demonstrate expertise in highly specialised and advanced technical, professional areas', 'design and apply research methods and communicate research to peers', 'conduct research' and 'take complete accountability for determining, achieving and evaluating person and group output' (SAQA, 2001a).

It seems clear that the contribution of this methodology to the wide range of key management skills as reflected in the critical cross-field outcomes is not sufficiently appreciated and great benefit could be gained by both students and business schools through repositioning and marketing research methodology.

For example, all seven assessable critical outcomes can be developed through the research process, as follows:

a. Collecting, analysing, organising and critically evaluating information is the prime purpose of the literature review that leads to the formulation of the research hypotheses, propositions or questions (Leedy \& Ormrod, 2001; Bendixen, 2002).

b. Identifying and solving a problem or problems is at the heart of the research process, which is usually not allowed to proceed without clear, definitive articulation of what the problem actually is (Leedy \& Ormrod, 2001). 
c. Demonstrating an understanding of the world as a set of interrelated systems can support the researcher in the gathering and evaluation of information and problem solving, since it is about seeing the whole as well as the parts, and seeing the connections between events that may appear to be unrelated (Senge, 1990). It is also about finding patterns, interrogating cause and effect relationships (Senge, 1990; McCaughan \& Palmer, 1994; Senge et al., 1994) and finding creative solutions to problems.

d. Communicating effectively using visual, mathematical and/or language skills in the modes of oral and/or written persuasion are developed in the research process at several stages. The proposal and the final document must be written in clear report format according to strict guidelines of academic acceptability (Bendixen, 2002). In order to conduct the research, the researcher must construct or locate a suitable instrument, persuade potential respondents to participate in the study, then gather the data from the respondents or conduct interviews, which may require additional advanced communication and persuasion skills. The analysis, organisation and evaluation of the data may require mathematical skills as well as the ability to communicate effectively using mathematical expressions, and the synthesis of the final report can clearly only be done with English language skills in the mode of written persuasion.

e. Organising and managing oneself responsibly and effectively is key to completing a research project. MBA students have typically completed their course work by the time they undertake the actual project, which needs to be fitted in with the return to work and attempted normalisation of life and relationships. It takes discipline and focus to complete, submit and graduate.

f. Using technology effectively enables the researcher to collect, analyse and organise information both during the literature review phase and when data-basing, analysing and presenting their findings. At the very least they should be able to use a word processing software package.

g. Working effectively with others as a member of a team, group, organisation or community may be more or less important depending on the nature of the research, but often, the research process is a lonely one, and students may benefit greatly by working in support groups.

There appears to be a general lack of awareness amongst students about the range of skills to be learnt via this methodology, since conversations with numerous students under supervision reveal a poor sentiment towards research generally. Conversations with other supervising faculty suggest concern with the lack of student ability to develop philosophical argument (demonstrating inductive and deductive reasoning), which may be linked to the finding (Boytatzis et al., 1995) that MBA graduates are not practical enough and are not able to utilise information sources adequately.

\section{Assessment of the CCFOs}

An important part of the development process is assessment, since this gives greater incentive to learn. Since assessments must incorporate the critical cross-field outcomes, these need to be made explicit in degree and course outcomes. The SAQA requirement for assessment of applied competence encompasses knowledge (foundational competence), skills (practical competence) and the ability to apply the learning in one's own or different contexts (reflexive competence) (SAQA, 2003). The ability to do this at NQF Level 8 requires critical and creative thinking abilities and a self-aware appreciation of one's own role and place within one's environment.

\section{Recommendations}

1. Empirical research should be undertaken to investigate the validity, appropriateness and relevance of the CCFOs and to explore other possible constructs that may be suitable.

2. Business Schools could benefit if they were to build an appreciation in MBA students and graduates of the business relevance and applications of research-based thinking and specifically link the critical cross-field outcomes to the research process

\section{Conclusion}

In this exploratory study, it was found that SAQA's CCFOs are perceived by the MBA graduates sampled to be relevant generic management meta-competencies, and further, that they were developed to a greater or lesser extent during their studies. Acknowledgement and practice of these competencies would, as supported by the literature, enable MBA graduates to perform better as managers and leaders. It is intended that this exploratory study will lay a foundation for further research in this area, which should extend into other fields and sectors of the economy, particularly that of education and teacher education.

If business school faculty can be persuaded that all of the critical cross-field outcomes are valid generic management meta-competencies, they need to "sell" the benefits of each to students, and then incorporate them into the MBA programme and develop them actively.

Thinking skills, in all their variations, underpin higher education. Thinking is inherent in a number of the critical cross-field outcomes - critical thinking, creativity, problem solving, evaluating information, systems thinking, learning effectively, how we think about our interactions with diverse others, being a responsible citizen, managing ourselves, applying the use of technology, exploring opportunities. These depend less on what we think and more on how we think. Since higher education teaches us how to think, the opportunities for integration of the critical cross-field outcomes abound. Business schools simply need to do it deliberately and with intent. 


\section{References}

Allen, R.E. \& Allen, S.D. 1997. Winnie-the-Pooh on problem solving: In which pooh, piglet and friends explore how to solve problems so you can too. London: Methuen Publishers.

American Management Association (AMA). 2001. 'American Management Association survey: Managerial skills and competence'. [online] URL:www.amanet.org/research/archives.htm. Accessed 9 April 2003.

Australia. 2003. Australian Qualifications Framework (AQF). 'National training information service.' [online] URL:http://www ntis.gov.au/cgi-

bin/waxhtml/ n ntis/std.wxh?page=1. Accessed 9 April 2003.

Bagayoko, D., Kelley, E.L. \& Hasan, S. 2000. 'Problem solving paradigm', College Teaching, 48(1): 24-28.

Bendixen, M. 2000. Academic style guide: Handbook for the preparation of research reports, project reports, research proposals, research papers, theses and dissertations. Silove, H. (Ed.) Johannesburg: University of the Witwatersrand.

Bird, A. \& Gamble, J. 1996. 'National Standards and Qualifications: A South African perspective'. In Proceedings of the Conference on the National Qualifications Framework. 22-24 April 1996 Technikon SA Conference Centre in Johannesburg. Pretoria: HSRC Publishers.

Bloom, B. S. 1956a. Taxonomy of educational objectives, Book 1. Cognitive domain. New York: Longman.

Bloom, B. S. 1956b. Taxonomy of educational objectives, Book 2. Affective domain. New York: Longman.

Boyatzis, R.E., Cowen, S.S. \& Kolb, D.A. 1995. Innovation in professional education: Steps on a journey from teaching to learning. San Francisco: Jossey-Bass.

Brookfield, S.D. 1987. Developing critical thinkers: Challenging adults to explore alternative ways of thinking and acting. San Francisco: Jossey-Bass Publishers.

Bruton-Simmonds, I. 1992. Mend your English or what you should have been taught at primary school. London: Ivy Publications.

Canfield, J., Hansen, M.V. \& Hewitt, L. 2000. The power of focus: How to hit your business, personal and financial targets with absolute certainty. Deerfield Beach, Florida: Health Communications, Inc.

Carmichael, T., Wallace, E. \& Rijamampianina, R. 2005. 'Section 2-3. Using corporate emotional intelligence for competitive advantage in strategic decision making'. In Kagan, J. \& Bohmert, A. (Eds.). Brain-based executive education. Johannesburg: Knowledge Resources, p.p. 93110.
Carmichael, T. \& Sutherland, M. 2005. 'A holistic framework for the perceived return on investment in an MBA', South African Journal of Business Management, 36(2): 57-70.

Carter, M.S. 1997. 'Psychological / sociological paradigms'. [online] URL: http://webpages.marshall.edu/ carter12/eda705a5.htm. Accessed 30 May 2003.

Charlton, G. 2000. Human habits of highly effective organisations. $1^{\text {st }}$ Edition. Pretoria: Van Schaik, p.p. 80-92.

Cryer, P. 1998. 'Transferable skills, marketability and lifelong learning: The particular case of post-graduate research students', Studies in Higher Education, 23(2): 207217.

Dauer, F.W. 1989. Critical thinking: An introduction to reasoning. New York: Barnes \& Noble.

Davies, T.R. 1996. 'Preparing for the MRCGP: How to read critically’, Update Magazine, June: 80-83.

Fitz-enz, J. 2000. 'The ROI of human capital: Measuring the economic value of employee performance', New York: Amacom, p.p.129-159.

Garratt, R. 1996. The fish rots from the head. London: Harper-Collins Business.

Goleman, D. 1995. Emotional intelligence. New York: Bantam Books.

Goleman, D. 2000. 'Leadership that gets results', Harvard Business Review, 78 (2): 78-90

Guiliani, R.W. 2002. Leadership. St Ives: Little, Brown Books.

Hager, P.J. 1996. 'National Standards and Qualifications: An international perspective'. In Proceedings of the Conference on the National Qualifications Framework. 2224 April 1996, Technikon SA Conference Centre in Johannesburg. Pretoria: HSRC Publishers.

Handy, C. 1994. The empty raincoat. London: Hutchinson.

Hanrahan, H.E. 1996. 'Education and training outcomes: Universal and professional perspectives. In Proceedings of the Conference on the National Qualifications Framework 22-24 April 1996, Technikon SA Conference Centre in Johannesburg. Pretoria: HSRC Publishers.

Hersey, P., Blanchard, K.H. \& Johnson, D.E. 1996. Management of organizational behaviour: Utilizing human resources. $7^{\text {th }}$ Edition. New Jersey: Prentice-Hall International, Inc.

Hofstede, G. 1994. 'Business Cultures', UNESCO Courier 00415278, 47 (4):12-16. 
Human Sciences Research Council (HSRC). 1995. Ways of seeing the National Qualifications Framework. Pretoria: HSRC Publishers.

Hunter, D., Bailey, A. \& Taylor, B. 1998. Co-operacy: A new way of being at work. Halfway House: Zebra Press.

Isaacs, S.B.A. 1995. An outcomes-based approach: South African initiatives. In Proceedings of the Conference on the National Qualifications Framework. 22-24 April 1996 Technikon SA Conference Centre in Johannesburg. Pretoria: HSRC Publishers.

Isaacs, S.B.A. 2000. The National Qualifications Framework and standards setting. Pretoria: SAQA.

Karelse, C-M. 1998. 'Smarter higher education: Information literacy adds value'. In The challenge to be relevant in the $21^{\text {st }}$ century: Abstracts and full text documents of papers and demos given at the International Association of Technological University Libraries Conference. Pretoria 1-5 June. Available from ERIC, ED434670.

Kelly, A. 1996. Making decisions based on data, Marketing News, 30 (22): 4.

King, M.E. 2002. King Report on corporate governance for South Africa 2002. Johannesburg: Institute of Directors.

Kirkwood, M. 2000. 'Infusing higher-order thinking and learning to learn into content instruction: A case study of secondary computing studies in Scotland', Journal of Curriculum Studies, 32 (4): 509-535.

Leedy, P. \& Ormrod, J. 2001. Practical research: Planning and design. New Jersey: Prentice-Hall.

Mager, R. F. \& Pipe, P. 1997. Analyzing performance problems. $3^{\text {rd }}$ Edition. Atlanta: The Centre for Effective Performance, Inc.

McCaughan, N. \& Palmer, B. 1994. Systems thinking for harassed managers. London: Karnac Books.

Meyer, T. 1996. Creating competitiveness through competencies: Currency for the $21^{\text {st }}$ century. Johannesburg: Knowledge Resources.

Meyer, T. \& Semark, P. 1998. 'A framework for the use of competencies for achieving competitive advantage', South African Journal of Business Management, 27(4): 96-103.

Miles, M.B. \& Huberman, A.M. 1994. Qualitative data analysis: An expanded sourcebook. $2^{\text {nd }}$ Edition. Thousand Oaks: Sage Publications.

Mintzberg, H. 2004. 'Managers not MBAs. San Francisco: Berrett-Koehler Publishers, 260.

Moorhead, G. \& Griffin, R.W. 1995. Organizational behaviour: Managing people and organizations. $4^{\text {th }}$ Edition. Boston: Houghton Mifflin Company.
Morris, D. 1982. The pocket guide to manwatching. London: Elsevier.

National Training Board (NTB). 1994. A Discussion Document on a National Training Strategy Initiative: A preliminary Report by the National Training Board, April 1994, Pretoria: National Training Board.

New Zealand. New Zealand Qualifications Authority (NZQA). 2000. [online] URL: http://www nzqa.govt.nz. Accessed 10 April 2003.

Nordstrom, K. \& Ridderstrale, J. 2002. Funky business: Talent makes capital dance. Stockholm: Bookhouse Publishing.

Pease, A. \& Dunn, P. 1995. Write language: The new secrets of writing letters that really work. Mona Vale, Australia: Pease Training Corporation.

Pease, A. 1993. Body language: How to read others' thoughts by their gestures. London: Sheldon Press.

Randall, S. 1993. 'People's education and 'nation building' for a New South Africa', Review of African Political Economy, 20(58):43-61.

Republic of South Africa (RSA). 1995. 'The South African Qualifications Authority Act number 58', Government Gazette, No 152. Pretoria: Government Printer.

Republic of South Africa (RSA). 1996. Lifelong learning through a National Qualifications Framework, Report of the Ministerial Committee for Development Work on the NQF: A discussion document. Pretoria: Government Printer.

Republic of South Africa (RSA). 1998. 'The Skills Development Act number 97', Government Gazette, No 1942. Pretoria: Government Printer.

Robbins, S.P. 2001. Organizational behaviour. $9^{\text {th }}$ Edition. New Jersey: Prentice-Hall.

Robson, C. 2002. Real world research. $6^{\text {th }}$ Edition. Oxford: Blackwell Publishing.

Rowley, J. \& Slack, F. 1998. 'The first post-graduate experience conference', Journal of Further and Higher Education, 22(3): 253-265.

Ruchlis, H. \& Oddo, S. 1990. Clear thinking: A practical introduction. New York: Prometheus Books.

Schoeman, C.T. 1997. 'Competencies for leadership in the future world of work.' Unpublished MBA Research Report, Johannesburg, University of the Witwatersrand.

Scotland. Scottish Qualifications Authority (SQA). 2003. 'Catalogue of National Qualifications Session 2003/2004,' SQA Publication BA 0788. Glasgow: SQA Publisher.

Senge, P. M. 1990. The fifth discipline: The art and practice of the learning organization. New York: Doubleday. 
Senge, P.M., Kleiner, A., Roberts, C., Ross, R.B. \& Smith, B.J. 1994. The fifth discipline fieldbook: Strategies and tools for building a learning organization. London: Nicholas Brealey Publishing.

Sloan, S. \& Spencer, L.M. 1991. Participant survey results: Hay sales force effectiveness seminar. Hay Management Consultants, Atlanta. Cited in Spencer, L.M. (Jr) \& Spencer, S.M. 1993. Competence at work: Models for superior performance. New York: John Wiley \& Sons, Inc.

South African Qualifications Authority (SAQA). 2000. The National Qualifications Framework: An overview. Pretoria: SAQA.

South African Qualifications Authority (SAQA). 2001a. The development of level descriptors for the NQF; Document for public comment: 3 December 2001 to 28 February 2002. Pretoria: SAQA.

South African Qualifications Authority (SAQA). 2001b. Criteria for the generation and evaluation of qualifications and standards within the National Qualifications Framework Revision 3. Policy Document SAQA 1430/00. Pretoria: SAQA.

South African Qualifications Authority (SAQA). 2003. Guidelines for the assessment of NQF registered unit standards \& qualifications. Pretoria: SAQA.

Spencer, L.M. (Jr) \& Spencer, S.M. 1993. Competence at work: Models for superior performance. New York: John Wiley \& Sons, Inc.

Stacey, A.G. 2005. 'Reliability and validity of the item means and standard deviations of ordinal level response data', Management Dynamics, 14 (3):2-25.

Szeftel, M. 2000. 'Between governance \& underdevelopment: Accumulation \& Africa's 'catastrophic corruption', Review of African Political Economy, 27(84):287-307.

Thomas, A. \& Bendixen, M. 2000. 'The management implications of ethnicity in South Africa, Journal of International Business Studies, 31(3): 507-519.

Thompson, L. 2003. 'Improving the creativity of organizational work groups', Academy of Management Executive, 17(1): 96-111.

Ulrich, D., Smallwood, N. \& Zenger, J. 1999. Results based leadership. Boston: Harvard Business School Press.

United Kingdom. 2000a. Guidance in using the Key Skills Units. Qualifications and Curriculum Authority Publications QCA99/48. Sudbury: QCA Publications.

United Kingdom. 2000b. 'Key skills explained'. [online] URL:http://www.dfee.gov.uk/progfile/index.htm.

Department for Education and Employment Publications, London. Accessed 10 April 2003.
United Kingdom. 2000c. 'The National Vocational Qualifications'. [online] URL: http://www.dfee.gov.uk/nvg/, Department for Education and Employment Publications, London. Accessed 10 April 2003. 